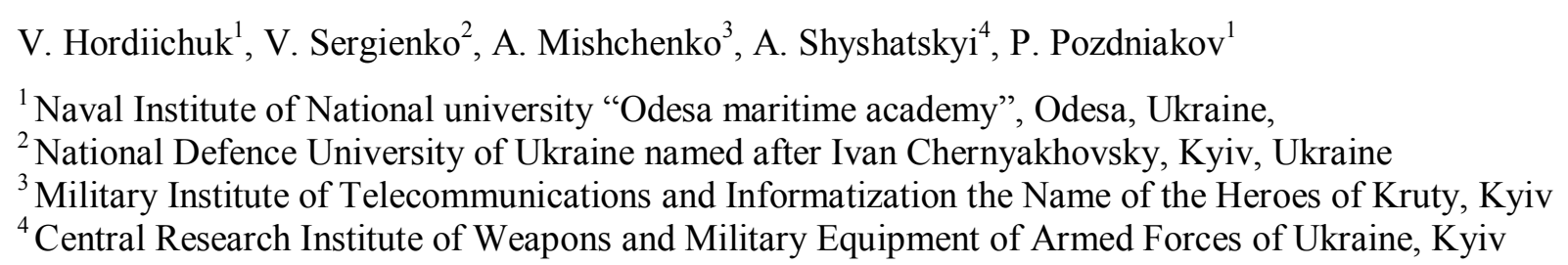

\title{
ANALYSIS OF TECHNICAL CHARACTERISTICS OF THE RADIOELECTRONIC INTELLIGENCE OF THE RUSSIAN FEDERATION
}

\begin{abstract}
One of the most important characteristics of radiocommunication systems and facilities that operate in the conditions of radio-electronic suppression is their secrecy, which is the ability of systems and radio communications to withstand the actions of radio-intelligence. Radiotechnical intelligence provides consistent execution of three main tasks: the detection of the fact of the operation of the system (devices) of radio communication (signal detection); determination of the structure of the detected signal and its basic parameters; disclosure of the information contained in the signal. Taking into account the Operations of the Joint Forces in the East of Ukraine caused by the armed aggression of the Russian Federation, an urgent question is raised regarding the analysis of the technical characteristics of the radio-electronic intelligence systems for determining the operation of the radiocommunication equipment of the Armed Forces of Ukraine and the structure of the type of signals used. The authors of this article conducted an analysis of the technical characteristics of the radio-electronic intelligence systems of the Russian Armed Forces to determine the operation of the radiocommunication equipment of the Armed Forces of Ukraine and the structure of the type of signals used. During the research, the authors used the basic provisions of the theory of communication, the theory of electronic warfare, the theory of signals and general scientific methods of analysis and synthesis. According to the results of the research, the following conclusions can be drawn: the frequency range of the electronic intelligence facilities of the Russian Armed Forces is much larger than the frequency range of the radiocommunication facilities of the Armed Forces of Ukraine and technically developed countries of the world; classical methods of increasing impedance and secrecy such as pseudo-random reconstruction of the operating frequency is not able to provide a given level of secrecy. In view of this, the direction of further research should be considered the development of scientific and methodical apparatus for increasing the structural secrecy of radio communications based on the use of time-signal structures.
\end{abstract}

Keywords: radio communication systems, radio resources, noise immunity, radio electron suppression, radio-electronic intelligence, secrecy.

\section{Introduction}

The main requirements for the modern military systems and radio communication facilities are [1-5]:

full mobility of all subscribers and elements of the radio communication system;

high efficiency of messages delivery to subscribers;

provision of a given quality of service to users in significant geographic areas in the conditions of use of both conventional and nuclear, biological and chemical weapons, as well as devices of electronic suppressing;

ensuring the continuity of combat management for all conditions of terrain;

high structural stability of the system (durability and reliability);

high bandwidth of communication channels;

high noise immunity of individual radio equipment and radio communication system as a whole.

One of the most important characteristics of systems and radio communication systems that operate in the conditions of radio-electronic suppression is their secrecy.

Under the covert sense of the ability of systems and radio communications to withstand the actions of radio engineering intelligence [1-5].

Radiotechnical intelligence provides the consistent fulfillment of three main tasks: the detection of the fact of the operation of the system (devices) of radio communication (signal detection); determination of the structure of the detected signal and its basic parameters; disclosure of the information contained in the signal.

In accordance with these tasks one can determine the main types of secrecy: energy, structural, informational, spatial and temporal.

Structural secrecy is aimed at excluding or significantly complicating the disclosure of the structure (sight) of the signals of the system (devices) of radio communication.

Taking into account the operation of the United Nations Operation in the East of Ukraine caused by the armed aggression of the Russian Federation, an urgent issue of the analysis of the technical characteristics of the radio-electronic intelligence systems complexes is determined to determine the operation of the radiocommunication equipment of the Armed Forces of Ukraine and the structure of the signals type that is used.

The purpose of this article is to analyze the technical characteristics of the electronic intelligence systems in determining the fact of the work of the radiocommunication facilities of the Armed Forces of Ukraine and the structure (type) of the signals used.

\section{Presentation of the main material}

Complexes of automated radiomonitoring (ARM) nowadays have become widely used as an instrument for solving such a problems as management of the use of radio frequency spectrum and control of electronic environment, including in the course of counter-terrorist 
operations. The main tasks of ARM are planned control of the parameters of standard devices and measurement of unintentional levels of obstacles, detection of unlicensed transmitters and determination of their location, measurement of energy coverage zones in assessing the quality of radio communications, determining the intensity of use of radio frequency resource.

ARM tools also solve information security tasks and serve as the basis for technical measures to counteract unauthorized removal of information, including special studies on side electromagnetic radiation and imprints.

Mobile automated systems of radioengineering and special monitoring of the effectiveness of information security and assessment of the electromagnetic environment of the МКТК-1 and МКТК-1A are designed to detect, measure parameters and determine the location of radio electronic equipment, assess the electromagnetic environment, detect and close the technical channels of information leakage.

The mobile automated complex of radioengineering and special control of information security efficiency МКТК-1A is intended for (Fig. 1, a) [6, 7]:

- operational control of operating modes and technical analysis of signals, placement and location of radio electronic equipment;
- control of the fulfillment of norms (requirements) for counteraction to radio and radio intelligence of foreign states;

- analysis and evaluation of the electromagnetic environment;

- control of radiation parameters of radio transmitters;

- search for the sources of unintentional radio interference;

- search for the special electronic devices for interception of information;

- detection of technical channels of information leakage due to side electromagnetic radiation and impulses, insufficient sound and vibration isolation;

- assessing the protection of objects from information leakage through technical channels;

- control of the protection of objects in the infrared and visible bands of electromagnetic waves;

- operational protection of information from leakage on vibroacoustic and radio channels.

The complex includes: automated workplace of radio control (AWP-RC); Workplace of special control with a complete set of remote equipment (WP-SP); communication equipment, power supply and life support.

Tactical and technical characteristics of MKTK-1A are given in the table 1 .

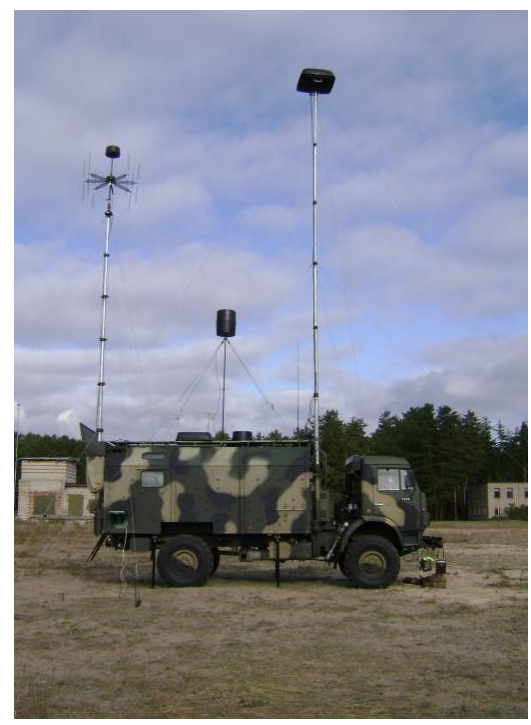

a

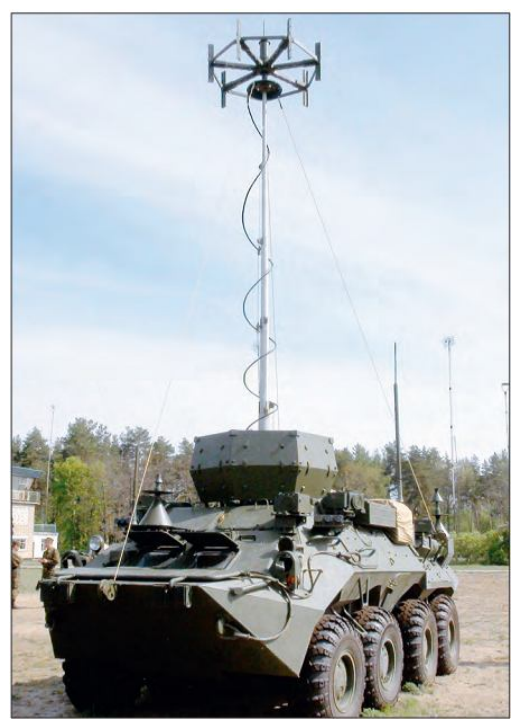

b

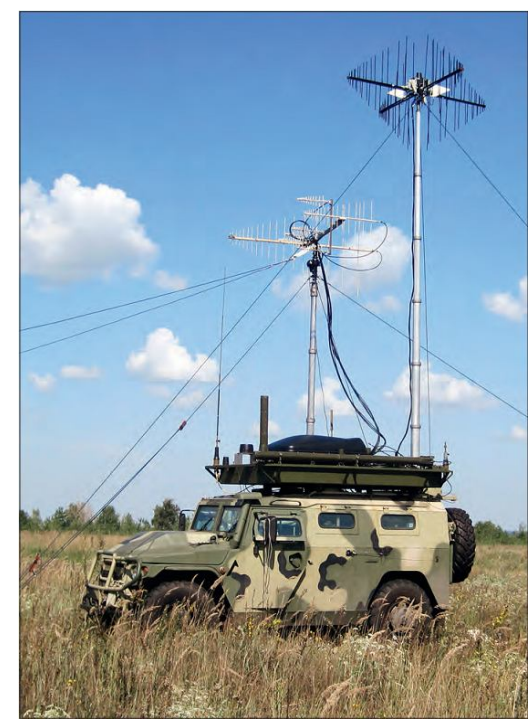

c

Fig. 1. Appearance of: $a-$ MKTK-1A; $b$ - the multifunctional complex of radio-electronic suppression of the RB-531BE; $\mathrm{c}-$ the mobile automated complex of radio inquiries and radio suppression (Leer-2)

Table 1 - Tactical and technical characteristics of МКТК-1A

\begin{tabular}{|l|l|}
\hline Frequency range of radiocontrol, $\mathrm{MHz}$ & $0,1-18000$ \\
\hline Accuracy of inclination, deg & $2-3$ \\
\hline Frequency range of side electromagnetic radiation control, MHz & $0,01-20000$ \\
\hline Frequency range of acoustic and vibration acoustic control, Hz & $10-20000$ \\
\hline Frequency range of detection of special electronic devices for intercepting information from radiosignals, $\mathrm{MHz}$ & $0,1-10000$ \\
\hline Range of communication with the use of a mobile radio station, km & $\leq$ than 20 \\
\hline The range of communication with the use of a portable radio station is not more than, km & 5 \\
\hline Time of deployment/collapse, min & 30 \\
\hline
\end{tabular}

Small-sized multifunctional systems of radio control, positioning and suppression RP-377L and
RP-377LA "Lorandit-AD". Small, multifunctional radio control complexes, positioning and suppression. 
RP-377L and RP-377LA "Lorandit" provide operative search, location and radio decay of radioelectronic devices of UHF radio communications of illegal armed groups, terrorist groups and interference sources for control and communication systems (fig. 2).

The RP-377L complex is located in two cases and four canvas bags for transferring combat personnel from two to three people and can be used both in field conditions and in conditions of medium and strongly rough terrain (fig. 2). Complex RP-377LA "Lorandit" is located on a high-capacity car (the type of car is determined by the requirements of the customer) and can be applied in field conditions and conditions of medium-sized terrain $[6,7]$.

Depending on the tasks solved complexes can be combined into a system of two or more complexes RP-377L and RP-377LA " Lorandit", one of which acts as a point of control system. Technical characteristics of the complexes are shown in the table 2.

The multifunctional complex of radio-electronic suppression of the RB-531BE is designed (fig. 1, b):

- for protection against radio-controlled mines and explosives, in a parking lot and in motion by devices of setting up broadband barriers to reception devices;

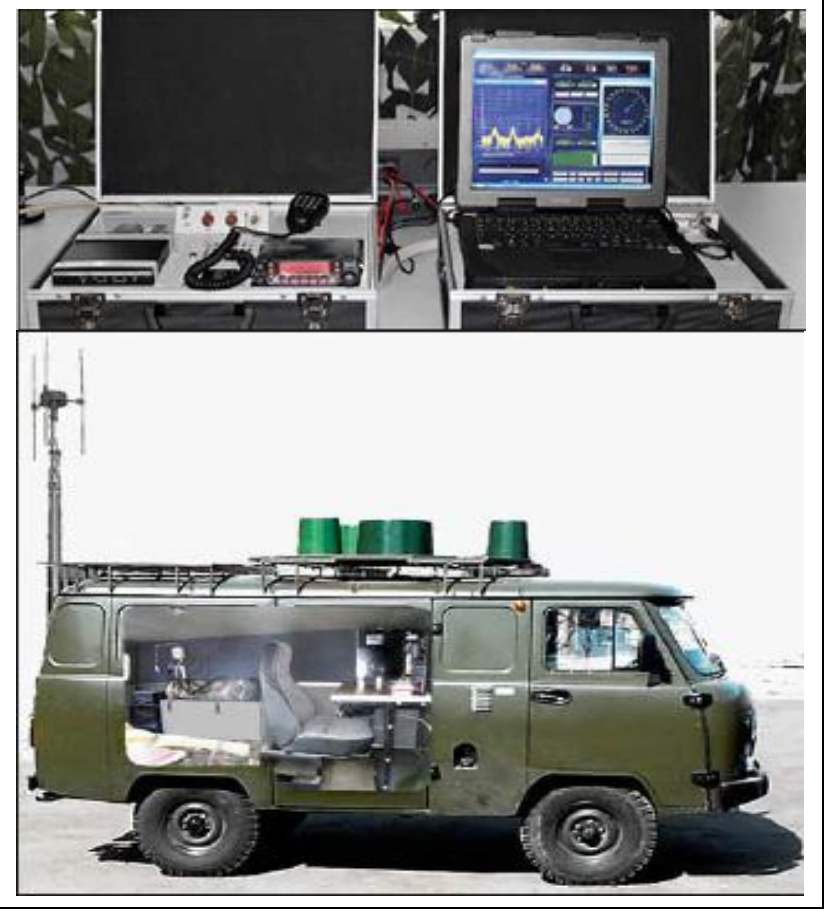

Fig. 2. Appearance of RP-377L

Table 2 - Technical characteristics of the complexes RP-377L and RP-377LA "Lorandit"

\begin{tabular}{|l|c|c|}
\hline Basic tactical and technical characteristics & RP-377L & RP-377LA \\
\hline Frequency range, MHz: & & \\
\hline detection & $20 \ldots 2000$ & $20 \ldots 2000$ \\
\hline positioning & $25 \ldots 2000$ & $25 \ldots 2000$ \\
\hline Detection Speed, MHz/sec & no less 10 & 65 \\
\hline Detection speed with downlink, MHz/s & no less 3,5 & 25 \\
\hline Median rotation error is not more than, deg & 3 & 3 \\
\hline Band of simultaneous review, kHz & 180 & 1200 \\
\hline The range of operating frequencies created by intentional interference, $\mathrm{MHz}$ & $137 \ldots 174,410 \ldots 470$ & $100 \ldots 500$ \\
\hline Power transmitter of intended interference, not less, W & $20 \ldots 40$ & 100 \\
\hline Closing time, min & no more than 10 & 10 \\
\hline
\end{tabular}

- radio-electronic intelligence, radio-telegraphy and interference with radio communication equipment (including cellular communication), which operate on fixed frequencies and in the FHSS mode on the parking lot and in motion.

The equipment of radio intrusion and radio suppression of the complex RB-531BE provides:

- detecting, radio-directing and suppressing sighting of the devices of UHF-radio communication, working with the FHSS with the reconstruction of the operating frequency speed of the 300 jump/second;

- detecting, radio-directing and radio-suppressing by noise-blocking frequency-modulated interference with UHF radio-communication devices operating with a FHSS with a speed up to 1,000 jumps per second;

- binding, technical analysis and auditory control of UHF radio communication in motion and in the parking lot;

- classification of signals of radio frequencies operating at fixed frequencies, with a probability of not less than 0.9 in the case of signal / noise ratio of $15 \mathrm{~dB}$ (in the frequency band of the signal).

Mobile automated radio-detecting and radiosuppressing complex (Leer-2) (Fig. 1, c).
The complex is intended for estimation of the electromagnetic environment, the radio information exploration of radio emission sources, and the obstruction of radio electronic devices.

Table 3 - Specifications of the REI PB-531BE subsystem

\begin{tabular}{|l|c|}
\hline \multicolumn{1}{|c|}{ Name of characteristic } & $\begin{array}{c}\text { The value } \\
\text { of the cha- } \\
\text { racteristic }\end{array}$ \\
\hline Frequency range, MHz: & $20 \ldots 2000$ \\
\hline detection & $25 \ldots 2000$ \\
\hline positioning & 5 \\
\hline $\begin{array}{l}\text { The medium-square error of positioning of } \\
\text { radio communication devices in a parking } \\
\text { lot with the developed AMY product, deg }\end{array}$ & 10 \\
\hline $\begin{array}{l}\text { Mean-square instrumental error of beaming } \\
\text { of radio communication devices in motion } \\
\text { with AMY made product, deg }\end{array}$ & 60 \\
\hline Two-signal dynamic range, dB, not less & \\
\hline $\begin{array}{l}\text { Frequency band review rate in the "Analisis } \\
\text { RES" mode: }\end{array}$ & 8000 \\
\hline $\begin{array}{l}\text { when it is found without placement, not } \\
\text { less, MHz/sec }\end{array}$ & 5000 \\
\hline $\begin{array}{l}\text { when it is located with the downlink, } \\
\text { not less, MHz/sec }\end{array}$ & \\
\hline \multicolumn{2}{|l}{} \\
\hline
\end{tabular}


Features of the complex:

- detection of sources of radio emission and determination of their location with anchoring to the digital terrain maps;

- setting of radio interruptions by various types of radio-electronic devices (including mobile communication systems);

- simulating the work of radio electronic devices.

- possibility of quasi-simultaneous suppression of 12 sources of radio emission;

- the possibility of continuous conducting of radio intrusion and radio suppression on the parking lot and in motion.

The main nomenclature of existing radio communication equipment of the UFH range of the Armed Forces of Ukraine and technically developed countries of the world have the following technical characteristics:

- frequency range - 30-512 MHz;

- power transmitter - 2-50 W;

- sensitivity of the receiver at the level $-110 \mathrm{~dB}$;

- signal type: $M$-position phase and $M$-position frequency manipulation.

From the fig. 3 it becomes evident that the devices of electronic intelligence of the Armed Forces of RF are capable of fully controlling the working range of frequencies of radio communications of the Armed Forces of Ukraine.

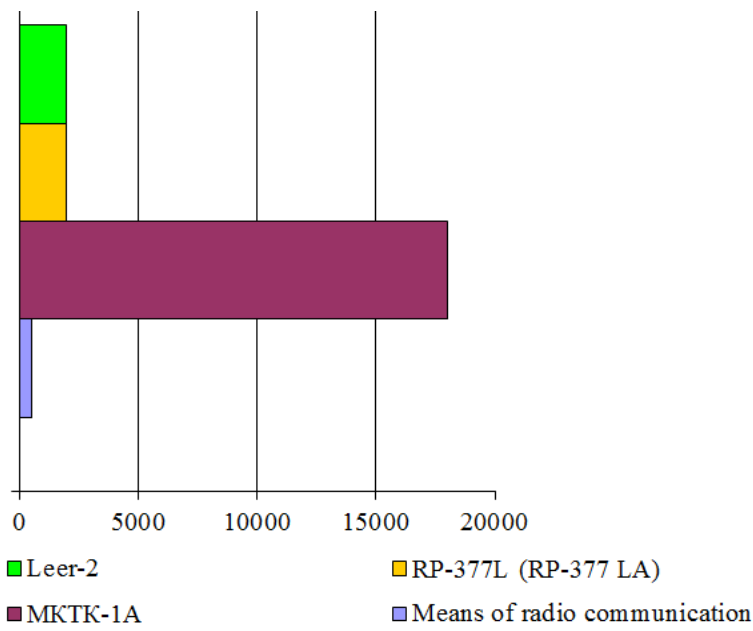

Fig. 3. Comparative analysis of the working range of radio frequencies of the Ukrainian Armed Forces and the technical capabilities of electronic intelligence

\section{Conclusion from the article}

In this article, the authors of the research conducted a comparative analysis of the technical characteristics of the electronic intelligence of the Armed Forces of the Russian Federation.
According to the results of the research, the following conclusions can be drawn:

1. Devices of electronic intelligence of the Armed Forces of the Russian Federation have the capability of full control of the radio lines and are capable of:

detecting information exchange between radio communication devices, determining the set of radio frequencies, frequency detection of a signal and disclosure of its structure;

calculation of interrelationship functions and memorization of time positions of information signals and metadata that accompany them for further suppression of the radio link or influence on the information flow;

decoding the received stream, set of statistics and analysis of encrypted messages;

familiarity with the content of messages transmitted over the radio;

simulation of signals transmitted in radio lines.

2. The frequency range of electronic intelligence facilities of the Armed Forces of the Russian Federation is considerably higher than the frequency range of the radiocommunication facilities of the Armed Forces of Ukraine and technically developed countries of the world.

3. The classic methods of increasing noise immunity and secrecy such as pseudo-random processing of the operating frequency are not able to provide a given level of secrecy.

4. Increased secrecy of radio communications of the Armed Forces of Ukraine may be achieved through organizational measures such as work with the minimum transmitter power, use of encryption tools (hardware and software); use of direct spectrum expansion technology.

5. Analysis of the literature shows that the general disadvantage of broadband systems is the use of signals with a regular structure, which makes it easy to detect them, to reveal the structure and to arrange an obstacle.

6 . Since the question of shifting the working range of communication frequencies that are out of range of electronic warfare devices at this time is not due to the complexity of its implementation, it is necessary to find ways to increase the energy secrecy of signals by devices of electronic intelligence and increase the cryptosecurity of messages $[8,9]$.

This issue will partially solve the use of timer signal constructions.

Taking into account the above, the direction of further research should be considered the development of scientific and methodical apparatus for increasing the structural secrecy of radio communication facilities based on the use of timer signal structures.

\section{REFERENCES}

1. Shyshatskiy, A.V., Bashkirov, O.M. and Kostina, O.M (2015). "Development of integrated systems and data for Armed Forces", Arms and military equipment, No 1(5), pp. 35-40. available at: http://journals.uran.ua/index.php/24140651/issue/view/1\%285\%29\%202015 (last accessed november 25,2018 ).

2. Minochkin, A. I. and Kuvshynov, O. V(2014). "Directions of increase of noise immunity of military systems and means of radio communication". Materials of VII-th scientific-technical conferences MITI SYT "Priority areas for the development of telecommunication systems and special purpose networks". pp. 29-33.

3. Kuvshynov, O. V(2009). "Adaptive management of devices of protection against military radio systems" Collection of scientific works MIKNY. No. 17. pp.125-130. 
4. Zhuk, O.G., Shyshatskiy, A.V., Zhuk, P.V. and Zhyvotovskyi, R.M (2017). "Methodological substances of management of the radio-resource managing systems of military radio communication”, Information Processing Systems, Vol. 5(151), pp. 16-25. https://doi.org/10.30748/soi.2017.151.02.

5. Kuvshinov, O.V., Shyshatskiy, A.V., Lyutov, V.V and Zhuk, O.G(2017). "Analysis of ways for increasing the secrecy of broadband radiocommunication systems " Scientific works of Kharkiv National University of Air Forces, No. 1(50), pp. 2428.

6. Popov, A.O., Tverdokhlibov, V.V(2014). "General tendencies of development of means of electronic warfare " Arms and military equipment, No. 4 (4), pp. 4-10.

7. Serhiienko, V.D., Popov, A.O., Zibin, S.D., Bychkov, A.N., Pidhorodetskyi, M.M (2017). "Analysis of the state of the art of multifunctional electronic warfare means and complexes." Modern Information Technologies In the sphere of security and defence, No.1(28), pp.135-143.

8. Zakharchenko, M.V., Gorokhov, S.M., Kochetkov, O.V., Hordiichuk V.V.and Shamshidin, E. B(2017). "Comparison of ensembles of code sets synthesized on the basis of several modules with ensembles realized on the basis of timer signal constructions", Information processing systems, No. 1(147), pp. 18-21. https://doi.org/10.30748/soi.2017.147.04.

9. Zakharchenko, M.V, Gorokhov, S.M., Kochetkov, O.V. and Hordiichuk V.V(2016)."Comparison of positional and timer coding", Collection of scientific works MITI, No 1, pp.59-63.

Рецензент: д-р техн. наук, проф. Г. В. Худов, Український державний університет залізничного транспорту, Харків Надійшла (received) 08.11.2018 Прийнята до друку (accepted for publication) 23.01.2019

\section{Аналіз технічних характеристик засобів радіоелектронної розвідки Російської Федерації}

\section{В. В. Гордійчук, В. Д. Сергієнко, А. О. Міщенко, А. В. Шишацький, П. В. Поздняков}

Однією з важливих характеристик систем і засобів радіозв'язку, які функціонують в умовах радіоелектронного подавлення $є$ їх скритність, що є здатністю систем і засобів радіозв'язку протистояти дії засобам радіотехнічної розвідки. Радіотехнічна розвідка передбачає послідовне виконання трьох основних задач: виявлення факту роботи системи (засобу) радіозв'язку (виявлення сигналу); визначення структури виявленого сигналу і його основних параметрів; розкриття інформації, яка міститься в сигналі. Враховуючи проведення Операції об'єднаних Сил на Сході України, що викликана збройною агресією РФ постає актуальне питання щодо аналізу технічних характеристик комплексів радіоелектронної розвідки щодо визначення факту роботи засобів радіозв'язку ЗС України та структури (виду) сигналів, що використовується. Авторами зазначеної статті проведений аналіз технічних характеристик комплексів радіоелектронної розвідки збройних сил Російської Федерації щодо визначення факту роботи засобів радіозв'язку ЗС України та структури (виду) сигналів, що використовується. В ході дослідження авторами були використані основні положення теорії зв'язку, теорії радіоелектронної боротьби, теорії сигналів та загальнонаукові методи аналізу та синтезу. За результатами проведеного дослідження можна зробити наступні висновки: діапазон частот засобів радіоелектронної розвідки Збройних Сил Російської Федерації є значно більшим за діапазон частот засобів радіозв'язку Збройних Сил України та технічно розвинених країн світу; класичні методи підвищення завадозахищеності та скритності такі як псевдовипадкова перестройка робочої частоти не змозі забезпечити заданого рівня скритності Враховуючи зазначене, напрямком подальших досліджень слід вважати розробку науково-методичного апарату підвищення структурної скритності засобів радіозв'язку на основі використання таймерних сигнальних конструкцій.

Ключові слова: системи радіозв'язку, радіоресурс, завадозахищеність, радіоелектронне подавлення, радіоелектронна розвідка, скритність.

\section{Анализ технических характеристик средств радиоэлектронной разведки Российской Федерации}

\section{В. В. Гордейчук, В. Д. Сергиенко, А. О. Мищенко, А. В. Шишацкий, П. В. Поздняков}

Одной из важных характеристик систем и средств радиосвязи, которые функционируют в условиях радиоэлектронного подавления есть их скрытность, которая есть свойством систем и средств радиосвязи противостоять действию средств радиотехнической разведки. Радиотехническая разведка предусматривает последовательное выполнение трёх основных задач: обнаружение факта работы системы (средства) радиосвязи (обнаружение сигнала); определение структуры обнаруженного сигнала и его основных параметров; вскрытие информации, которая содержится в сигнале. Учитывая проведение Операции объединённых Сил на Востоке Украины, которая вызвана вооруженной агрессией РФ становится актуальным вопрос анализа технических характеристик комплексов радиоэлектронной разведки относительно определение факта работы средств радиосвязи ВС Украины и структуры (вида) сигналов, которые используются. Авторами данной статьи проведён анализ технических характеристик комплексов радиоэлектронной разведки вооружённых сил Российской Федерации по выявлению факта работы средств радиосвязи ВС Украины и структуры (вида) сигналов, которые используются. В ходе исследования авторами были использованы основные положения теории связи, теории радиоэлектронной борьбы, теории сигналов и общенаучные методы анализа и синтеза. По результатам проведенного исследования можно сделать следующие выводы: диапазон частот средств радиоэлектронной разведки вооруженных сил Российской Федерации есть значительно большим чем диапазон частот средств радиосвязи Вооружённых Сил Украины и технически развитых стран мира; классические методы повышения помехозащищённости и скрытности такие как псевдослучайная перестройка рабочей частоты не в состоянии обеспечить заданного уровня скрытности. Учитывая данное, направлением дальнейших исследованием следует считать разработку научно-методического аппарата повышения структурной скрытности средств радиосвязи на основе использования таймерных сигнальных конструкций.

Ключевые слова: системы радиосвязи, радио ресурс, помехозащищенность, радиоэлектронное подавление, радиоэлектронная разведка, скрытность. 